\title{
Pengaruh Temperatur pada Proses Pencairan Batubara Antrasit Menggunakan Pelarut Short Residue
}

\author{
Lince Muis ${ }^{1, *}$, Hasrul Anwar ${ }^{2}$, Muhammad Haviz $^{3}$ \\ Program Studi Teknik Kimia Fakultas Teknik Universitas Jambi \\ *Jl. Tri Brata, Pd. Meja, Mestong, Kabupaten Muara Jambi, Jambi 36361 \\ email:ilincemuisismet@yahoo.com
}

\begin{abstract}
ABSTRAK
Proses konversi atau pencairan batubara hanya dijelaskan oleh proses konversi batubara dari padatan menjadi produk cair menggunakan reaktor yang disandarkan sesuai dengan metode yang digunakan pada suhu dan tekanan hidrogen yang cukup tinggi dengan bantuan katalis dan medium pelarut. metode yang digunakan dalam penelitian ini adalah pirolisis. Reaktor yang digunakan yaitu reactor jenis fluidized bed reactor dan menggunakan pendinginan untuk mengubah fase uap menjadi liquid. Menurut hasil terdekat dari batubara menunjukkan bahwa sampel adalah batubara termasuk antrasit. Berdasarkan karakterisasi batubara menggunakan XRD dan SEM-EDX. ada beberapa kandungan mineral dalam batubara seperti $\mathrm{SiO}_{2}, \mathrm{Al}_{2} \mathrm{O}_{3}$ dan $\mathrm{Fe}_{2} \mathrm{O}_{3}$ dan di dalam batubara hasil EDX menunjukkan bahwa konstituen batubara terdiri dari $\mathrm{C}, \mathrm{Si}, \mathrm{Al}$, $\mathrm{O}$ dan S. Selain itu setelah dianalisa nilai kalornya ternyata sampel yang digunakan mendekati nilai kalor batubara jenis antarsit. Dalam proses konversi batubara menggunakan metode pirolisis, temperatur memiliki pengaruh yang signifikan. Efek pada konversi dan hasil dengan suhu yang lebih tinggi semakin banyak batubara diubah menjadi produk cair. kenaikan suhu dilakukan dari $550^{\circ} \mathrm{C}, 600^{\circ} \mathrm{C}, 650^{\circ} \mathrm{C}, 700^{\circ} \mathrm{C}, 750^{\circ} \mathrm{C}$. Hasil konversi batubara berdasarkan analisis GC-MS batubara yang potensial sebagai sumber bahan baku bensin. ini karena GC-MS senyawa yang terbentuk pada konversi batubara sama dengan hidrokarbon yang ditemukan dalam bensin, yang merupakan senyawa hidrokarbon rantai pendek dengan rantai $\mathrm{C}_{7}-\mathrm{C}_{12}$
\end{abstract}

Kata kunci: batubara, bensin, hidrokarbon

\section{PENDAHULUAN}

Perkembangan teknologi, transportasi maupun industri sangat tergantung pada minyak dan gas bumi. Menurut data Badan Pusat Statistik (2014), jumlah kendaraan bermotor di Indonesia mengalami kenaikkan setiap tahun. Oleh karena itu, energi yang dibutuhkan juga bertambah seiring dengan kebutuhan kendaraan yang semakin memuncak. Besarnya jumlah kebutuhan energy mengakibatkan terjadinya eksplorasi minyak bumi secara terus menerus.

Menurut Kementerian ESDM (2006), Jambi merupakan salah satu daerah penghasil batubara terbesar ketiga di Sumatra setelah Sumatra Selatan dan Riau. Jambi memiliki 1.862,39 juta ton batubara dengan kalori rendah $<5100$ sebanyak 51,13 juta ton. Batubara merupakan salah satu energy utama di Indonesia yang dalam pemanfaatannya dapat menjadi energy alternatif yang menjanjikan dengan cara dikonversi ke bentuk cair.

Secara sederhana, proses pencairan batubara adalah proses konversi batubara padat menjadi suatu produk cair, pada suhu dan tekanan hidrogen yang cukup tinggi dengan bantuan katalis dan media pelarut. Pencairan batubara dapat dilakukan dengan dua cara, yaitu pencairan tidak langsung dan pencairan langsung (Klenpeter, 1983; Dong Shi, 2008). Banyak faktor yang mempengaruhi proses pencairan batubara baik yang berhubungan dengan karakteristik batubara itu sendiri ataupun kondisi operasional pencairan yang diterapkan. Kondisi operasi adalah bagian penting yang mempengaruhi proses dan hasil konversi pencairan batubara. Kondisi operasi tersebut terdiri atas suhu, waktu, dan tekanan. Huda et al., (2009) melaporkan bahwa pencairan batubara peringkat rendah (batubara Pendopo) Sumatera Selatan dengan nilai kalori 4.844 $\mathrm{kal} / \mathrm{g}$.

Batubara Pendopo menghasilkan konversi pencairan sampai $80 \%$ dengan temperature maksimum pencairan adalah $40^{\circ} \mathrm{C}$, sedangkan Talla (2009), studi pencairan batubara peringkat rendah Sorong. Hasil konversi pencairan batubara Sorong sebesar $89,94 \%$ dengan temperature pencairan $400^{\circ} \mathrm{C}$. Wang et al., (2010) menyatakan bahwa studi pencairan batubara lignit dengan temperatur $200^{\circ} \mathrm{C}$ dan dengan hasil 
pencairan mencapai 50,7\%. Penelitian batubara dengan nilai kalor rendah juga telah dilakukan oleh Karaca (2006), pencairan batubara lignit dengan menggunakan katalis $\mathrm{Fe}_{2} \mathrm{O}_{3}$ dan $\mathrm{Mo}(\mathrm{CO})_{6}$. Waktu reaksi pencairan dari 30-120 menit akan meningkatkan gugus policyclicaromatik dan rantai alkana. Demikian juga dengan meningkatnya temperature reaksi pencairan dari $400{ }^{\circ} \mathrm{C}-425{ }^{\circ} \mathrm{C}$ terjadi peningkatan minyak yang dihasilkan.

Oleh sebab itu, pada penelitian ini mengkaji "Pengaruh Suhu Pada Pencairan Batubara Dengan Menggunakan Pelarut Short Residue" dengan harapan bias memperoleh suhu dan tekanan yang optimum dalam proses pencairan, serta dapat diterapkan pada skala komersial mengingat Jambi adalah penghasil batubara ke-3 setelah Sumatera Selatan dan Riau. Batubara yang dihasilkan sebagian besar adalah batubara jenis lignit atau batubara dengan nilai kalor $\leq 5000$ (Sumber Daya Geologi, 2011).

\section{METODE PENELITIAN}

Bahan yang digunakan dalam penelitian ini adalah batubara PT. Daya Bambu Kabupaten Tebo, Provinsi Jambi, pelarut short residue, katalis $\gamma-\mathrm{Al}_{2} \mathrm{O}_{3}$.

Alat yang digunakan dalam penelitian ini erlenmeyer, gelas ukur, gelas kimia, corong pisah, cawan crussible, cawan alumunium, reaktor, oven, furnace, ayakan, grinder, neraca analit, Scanning Electron Microscopy, X-Ray Diffraction, Gas Cromatografy Mass Spectroscopy.

Preparasi awal sampel batubara yang diperoleh dari hasil pertambangan PT Daya Bambu Kabupaten Bungo dimulai dengan proses grinding dan pengayakan sehingga menghasilkan sampel batubara dengan berbagai ukuran yaitu 60 mesh, 100 mesh 125 mesh dan 170 mesh. Sampel dengan ukuran 60 mesh dilakukan uji analisis proksimat, 100 mesh untuk uji nilai kalor, serta 170 mesh untuk pencairan.

Jumlah Air (Inherent Moisture). Penetapan Inherent Moisture di dalam sampel dikerjakan berdasarkan ASTM D 3173-11. Oven diatur terlebih dahulu hingga suhunya terkalibrasi, yaitu 105$110^{\circ} \mathrm{C}$.Massa dari cawan aluminium kering dan bersih ditimbang bersama tutupnya dan dicatat sebagai $\mathrm{M}_{1}$ kemudian timbang sampel 1,0000 $\pm 0,0010 \mathrm{~g}$ kedalam cawan tersebut. Massa cawan, sampel, beserta tutupnya dicatat sebagai $\mathbf{M}_{2}$. Cawan diletakan di atas nampan aluminium lalu dibuka tutupnya. Kemudian nampan dimasukkan ke dalam oven setelah suhu oven mencapai set point $107^{\circ} \mathrm{C}$ dan dikeringkan selama 1 (satu) jam.

$$
\operatorname{IM}(\%)=\left[\frac{A-B}{A}\right] \times 100 \%
$$

Kadar Abu (Ash Content). Penetapan Ash Content di dalam sampel dikerjakan berdasarkan ASTM D 3174-12. Crusibel kosong yang bersih ditimbang dan dicatat massanya sebagai $\mathrm{M}_{1}$ kemudian ditimbang sampel $1.0000 \pm 0.0010 \mathrm{~g}$ ke dalam crusibel dan dicatat massanya sebagai $\mathrm{M}_{2}$. Crusibel ditempatkan di dalam furnace pada suhu kamar menggunakan gegep panjang. Kemudian tekan tombol sesuai setting yang diperlukan yaitu $T_{1}=450, T_{2}=750$, time ${ }_{1}=60$, dan time $2=120$. Setelah pemprograman diatas ditekan tombol start. Biarkan sampai lampu time out menyala. Buka sedikit pintu furnace untuk mendinginkan contoh hingga $+300^{\circ} \mathrm{C}$. Pindahkan crusibel dari furnace menggunakan gegep panjang dan letakkan di atas plat logam tahan panas. Biarkan dingin selama 10 menit dan pindahkan ke dalam desikator. Timbang crusibel dan residu sebagai $\mathrm{M}_{3}$. Buang residu, cawan dibersihkan dan ditimbang crusibel kosong sebagai $\mathbf{M}_{4}$.

$$
\operatorname{Ash}(\%)=\left[\frac{A-B}{C}\right] \times 100 \%
$$

Kadar ZatTerbang (Volatile Matter). Penetapan Volatile matter di dalam sampel dikerjakan berdasarkan ISO 562-2010. Suhu furnace dinaikkan hingga $900^{\circ} \mathrm{C}$ (set point yang terkalibrasi). Timbang dan catat massa crusibel VM kosong yang bersih dan penutupnya sebagai $\mathrm{M}_{1}$. Timbang contoh hingga $1.0000 \pm$ $0.1000 \mathrm{~g}$ ke dalamcrusibel VM tersebut. Kemudian tutup dengan penutupnya. Catat massa crusibel. Penutup dan sampel sebagai $\mathbf{M}_{2}$. Letakkan crusibel pada penyangga dan masukkan ke dalam furnace. Mulai nyalakan stopwatch dan biarkan selama 7 menit. Pindahkan dari furnace dan tempatkan dalam tempat datar. 
Kemudian dipindahkan ke dalam desikator dan didiamkan selama 7 menit. Timbang crusibel, penutupnya dan sampel sebagai $\mathrm{M}_{3}$.

$$
\begin{gathered}
\text { Lost }(\%)=\left[\frac{A-B}{C}\right] \times 100 \% \\
\% \mathrm{VM}=\% \text { lost }-\% \mathrm{IM}
\end{gathered}
$$

KarbonPadat (Fixed Carbon). Didefinisikan sebagai material yang tersisa, setelah berkurangnya moisture, volatile matter dan ash.

$$
\mathrm{FC}=100-(\% \mathrm{IM}+\% \mathrm{Ash}+\% \mathrm{VM})
$$

Heating Value (HV) ( Calorific Value/ Nilaikalor). Berdasarkan prosedur yang dilakukan Sutrisno (2015), Bucket diisi dengan aquades sebanyak 2L kemudian sebanyak 0,5 g sampel berukuran 100 mesh ditimbang mengunakan cawan khusus, lalu ditempatkan didalam gantungan yang sudah dipasang kawat(fuse wire) setelah itu dimasukan ke dalam Bomb Calorimeter dan diisi dengan gas oksigen $\left(\mathrm{O}_{2}\right)$. Bomb Calorimeter dimasukan kedalam bucket kemudian disambungkan dengan terminal Bomb fuse dan tekan tombol start. Dibiarkan sampai proses analisis selesai dan data keluar.

\section{Karakterisasi Sampel}

\section{Karakterisasi menggunakan XRD (X-Ray Diffraction)}

Batubara (digrinding) dan diayak dengan ukuran 100 mesh dan dilakukan karakterisasi XRD (X-Ray Diffraction) PANalytic Xpert ${ }^{3}$ powder gonimeter PW 3050/60 type of bragg-brentano. Sampel serbuk dimasukan ke dalam sampel holder dan ditekan sepadat mungkin, kemudian XRD diatur dalam keadaan ON danatur computer, selanjutnya tunggu sampai grafik pada computer selesai dan dianalisis hasilnya.

\section{Karakterisasi menggunakan SEM (Scanning Electron Microscopy)}

Batubara dihaluskan (digrinding) dan diayak hingga memiliki 3 variasi luas permukaan yaitu 200 mesh kemudian dikarakterisasi menggunakan Scanning Electron Microscopy berdasarkan prosedur yang dilakukan Dedy (2015) set specimen pada specimen holder lalu ditarik handle pada tempat sampel dan sampel diletakan pada sampel holder yang tersedia, selanjutnya tutup kembali bagian untuk proses pemvacuman dan tunggu sampai Gambar muncul di desktop, diklik icon software SEM pada PC, diklik icon start untuk memulai proses observasi pada sampel.

\section{Pencairan Batubara}

Batubara dihaluskan (digrinding) dan diayak dengan ukuran 170 mesh. Masukan sampel ukuran170 mesh sebanyak 200 gram dan 300 gram pelarut ke dalam Reactor selama3 jam dengan suhu pertama 400, 425,450 , dan $475^{\circ} \mathrm{C}$ dengan persentase katalisator $\gamma-\mathrm{Al}_{2} \mathrm{O}_{3}$ yang ditambahkan untuk setiap pencairan sesuai ketentuan yaitu $3 \%$ dari batubara (Talla,2009).

\section{Karakterisasi menggunakan GC-MS (Gas Cromatografy Mass Spectroscopy)}

Minyak hasil pencairan di rotary evaporator dan dianalisis mengunakan GC-MS Shimadzu Qp 5000. Sampel sebanyak $1 \mu \mathrm{L}$ diinjeksikan ke GC-MS yang dioperasikan menggunakan kolom kaca panjang $25 \mathrm{~m}$, diameter $0,25 \mathrm{~mm}$ dan ketebalan $0,25 \mu \mathrm{m}$ dengan fase diam CP-Sil 5CB dengan temperatur oven diprogramkan antara $70-270^{\circ} \mathrm{C}$ dengan laju kenaikan temperatur $10^{\circ} \mathrm{C} /$ menit, gas pembawa helium bertekanan $12 \mathrm{kPa}$, total laju $30 \mathrm{~mL} /$ menit dan split rasio sebesar 1:50 (Prasetya, 2006).

\section{HASIL DAN PEMBAHASAN \\ Analisis Proksimat Batubara}

Merupakan analisis sederhana untuk menentukan zat yang terkandung didalam batubara yang meliputi kadar air, abu, zat terbang, karbon padat, dan nilai kalor. hasil analisa proksimat berdasarkan ASTM 
menunjukan bahwa batubara PT. Daya bambu termasuk batubara jenis sub-bituminus. Adapun hasil uji analisis proksimat disajikan pada Tabel 1.

Tabel 1. Analisis proksimat batubara PT. Daya Bambu Kab. Tebo

\begin{tabular}{lcc}
\hline \multicolumn{1}{c}{ Parameter analisa } & Hasil & ASTM \\
\hline Kadar air (\%) & 11,88 & $\pm 10-25 \%$ \\
Kadar Abu (\%) & 5,73 & $3-10 \%$ \\
Kadar zattebang (\%) & 32,61 & $15-45 \%$ \\
Karbonpadat (\%) & 51,58 & $50-70 \%$ \\
Nilaikalor (Btu/b) & 9940 & $8300-11500$ Btu/b \\
\hline
\end{tabular}

Batubara sub-bituminus merupakan batubara kelas menengah karena batubara jenis ini sedikit terdapat pengotor seperti mineral-mineral yang terkandung didalamnya. Dalam hal ini telah ditunjukkan pada hasil uji kadar abu yang diperoleh 5,73\%. Dalam penelitian yang dilakukan oleh Aswati (2011) batubara yang memiliki kandungan mineral yang lebih besar memiliki tingkat kereaktifan yang lebih rendah. Adanya kandungan mineral pada sampel batubara dapat dilihat pada hasil analisa dengan menggunakan instrumen XRD dan juga SEM-EDX.

\section{Karakterisasi}

\section{Karakterisasi menggunakan XRD (X-Ray Diffraction)}

XRD (X-Ray Defraksi) adalah istrumen yang bertujuan untuk menentukan pola difraksi dan struktur kristal dari mineral-mineral yang terdeteksi dalam batubra. Analisis XRD ini juga dapat digunakan untuk mengidentifikasi fasa kristalin serta ukuran kristal dalam material dengan menentukan parameter struktur kisi. Mineral merupakan suatu bahan padat homogen yang terbentuk secara anorganik, dan mempunyai komposisis kimia dalam perbandingan tertentu dan mempunyai atom-atom yang tersusun mengikuti suatu pola yang sistematis. Pada analisa ini digunakan instrumen PANalytic Xpert ${ }^{3}$ Powder goniometer PW 3050/60 type bragg-brento yang beroperasi di Fakultas Teknik Universitas Jambi. Hasil analisa batubara PT. Daya Bambu Kabupaten tebo dapat dilihat pada Gambar 1.

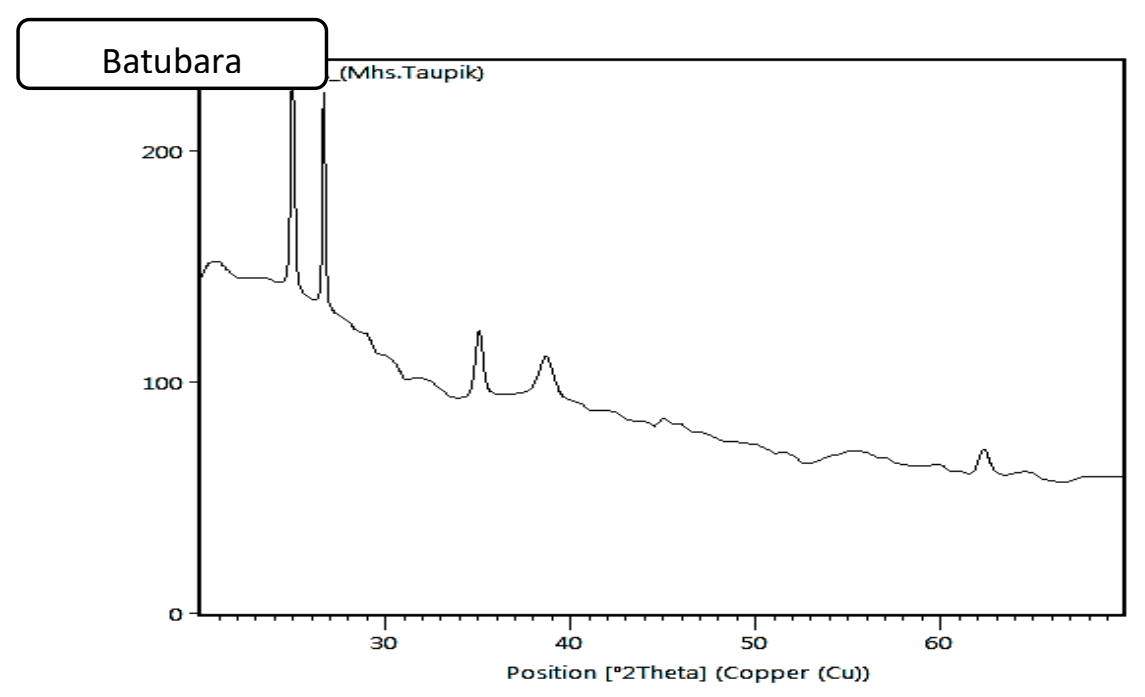

Gambar 1. Grafik XRD batubara PT. Daya Bambu Kab. Tebo

Dari Gambar 1. Menunjukan adanya tiga puncak tajam pada 2 $\theta$. Adapun daftar $2 \theta$ yang muncul di plotkan dalam Tabel 2. 
Tabel 2. Daftar Nilai $2 \theta$ dari Analisis XRD pada Batubara

\begin{tabular}{ccc}
\hline Harga 20$\left[^{0}\right]$ & d-spacing $[\AA \mathbf{A}]$ & $\mathbf{M i n e r a l}$ \\
\hline 20.860 & 4.2549 & $\mathrm{SiO}_{2}$ \\
26.640 & 3.3434 & $\mathrm{SiO}_{2}$ \\
35.037 & 2.5611 & $\mathrm{Al}_{2} \mathrm{O}_{3}$ \\
36.544 & 2.4568 & $\mathrm{SiO}_{2}$ \\
38.648 & 2.3297 & $\mathrm{Fe}_{2} \mathrm{O}_{3}$ \\
39.465 & 2.3297 & $\mathrm{SiO}_{2}$ \\
40.300 & 2.2361 & $\mathrm{SiO}_{2}$ \\
42.450 & 2.1277 & $\mathrm{SiO}_{2}$ \\
45.793 & 1.9798 & $\mathrm{SiO}_{2}$ \\
50.139 & 1.8179 & $\mathrm{SiO}_{2}$ \\
50.622 & 1.8017 & $\mathrm{SiO}_{2}$ \\
54.875 & 1.6717 & $\mathrm{SiO}_{2}$ \\
55.325 & 1.6591 & $\mathrm{SiO}_{2}$ \\
57.235 & 1.6082 & $\mathrm{SiO}_{2}$ \\
59.960 & 1.5415 & $\mathrm{SiO}_{2}$ \\
64.036 & 1.4528 & $\mathrm{SiO}_{2}$ \\
62.275 & 1.4908 & $\mathrm{Fe}_{2} \mathrm{O}_{3}$ \\
\hline
\end{tabular}

Berdasarkan difraktogram $\mathrm{SiO}_{2}$ mendominasi dengan intensitas puncak tertinggi yakni posisi $2 \theta$ berada pada 24,9662 dan 26,6508 dengan nilai d-spacing [ $\AA$ ] 3.56665 dan 3.34490. Hasil analisis ini sama yang telah dilaporkan Winda (2016) bahwa batubara sub-bituminus didominasi oleh $\mathrm{SiO}_{2}$ dari 4 mineral yang muncul yakni $\mathrm{SiO}_{2}, \mathrm{CaCO}_{3}, \mathrm{Fe}_{2} \mathrm{O}_{3}, \mathrm{Al}_{2} \mathrm{O}_{3}$.

\section{Karakterisasi Scanning Electron Microscopy-Electron Dispersive X-ray (SEM-EDX) Batubara}

Analisa dengan SEM-EDX bertujuan untuk mengetahui morfologi permukaan serta unsur-unsur penyusun batubara. Seperti yang ditunjukkan pada Gambar 2.
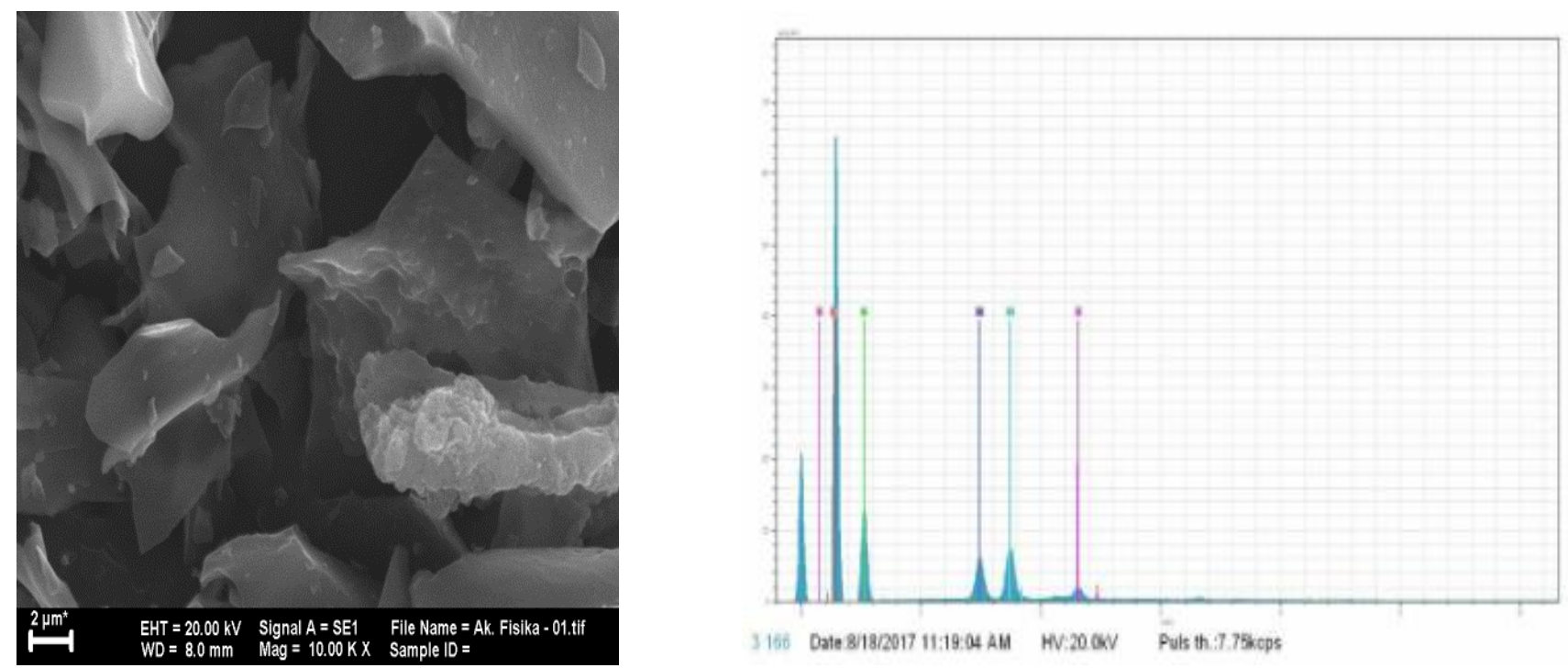

Gambar 2. Hasil EDX Batubara Pada Spot 10.00 K

Gambar 2. Menunjukan morpologi batubara terlihat padat dan tidak ada pori. Berdasarkan EDX, batubara tersusun dari unsur-unsur seperti yang terdapat didalam Tabel dibawah ini: 
Tabel 3.Persentase Unsur-Unsur yang Terkandung Didalam Batubara

\begin{tabular}{ccc}
\hline Unsur & No. atom & Persentase \\
\hline $\mathrm{C}$ & 6 & 48.17 \\
$\mathrm{O}$ & 8 & 44.22 \\
$\mathrm{Si}$ & 14 & 3.39 \\
$\mathrm{Al}$ & 13 & 3.18 \\
$\mathrm{~S}$ & 16 & 1.04 \\
\hline
\end{tabular}

Dari Tabel 3 unsur $\mathrm{C}$ (karbon) merupakan unsur yang dominan didalam batubara. dengan kadar 48.17\% dan Oksigen (O) 44.22\%. Hal ini dapat dilihat dari persentase dari masing-masing unsurnya. Dari hasil analisis EDX karbon memiliki persentase yang besar yaitu 48.17\%. Menurut speight (2005) kandungan karbon pada batubara sub-bituminus didapat sebesar 50-70\%. Hal ini juga dilaporkan oleh Nukman (2007) bahwa batubara subbituminus bukit Asam Palembang memiliki kandungan karbon sebesar 56,91\% dan batubara subbituminus dari kalimatan selatan memiliki kandungan karbon sebesar 69,16\%. Dari hasil analisis bahwa batubara sub-bituminus memiliki kandungan karbon (C) $\pm 50 \%$ dari batubara. Hal ini membuktikan bahwa penyusun utama batubara adalah karbon.

\section{Konversi batubara \\ Pengaruh Temperatur terhadap Konversi}

Data konversi batubara disajikan dalamTabel 4.

Tabel 4. Data konversi batubara dengan 2 kali pengulangan

\begin{tabular}{cccccccccc}
\hline Suhu & & Hasil & \multicolumn{2}{c}{ Residu } & \multicolumn{3}{c}{ Konversi } & \multicolumn{3}{c}{ Yield } \\
& 1 & & 2 & 1 & 2 & 1 & 2 & 0,0126 \\
\hline 400 & 63 & & 60 & 181,9 & 182,3 & 9,05 & 8,85 & 0,012 \\
425 & 65 & & 58 & 181,7 & 182,9 & 9,15 & 8,55 & 0,013 & 0,0116 \\
450 & 70 & & 69 & 165,4 & 165,5 & 17,3 & 17,25 & 0,014 & 0,0138 \\
475 & 71 & 73 & 163,8 & 164,1 & 18,1 & 17,95 & 0,0142 & 0,0146 \\
\hline
\end{tabular}

Dari Tabel 4 dapat dilihat pada konversi dengan 2 kali pengulangan didapat data yang tidak jauh berbeda pada konveri 1 dan 2. Dari Tabel menunjukkan kenaikan suhu mempengaruhi terhadap hasil konversi yaitu dengan meningkatnya suhu maka semakin banyak juga batubara yang terkonversikan menjadi produk cair. hal yang berbeda pada massa residu yaitu semakin tinggi suhu maka semakin ringan pula massanya. Adapun penurunan residu ini sesuai dengan pernyataan Zhang dkk (2007) dan Dong K.P dkk (2010) Residu yang menurun menunjukan bahwa bahan baku terdekomposisi lebih banyakseiring dengan meningkatnya suhu. Dari data pada Tabel 8 kenaikan suhu terhadap hasil konversi dari 2 kali pengulangan dapat kita bandingkan pada Gambar 3.

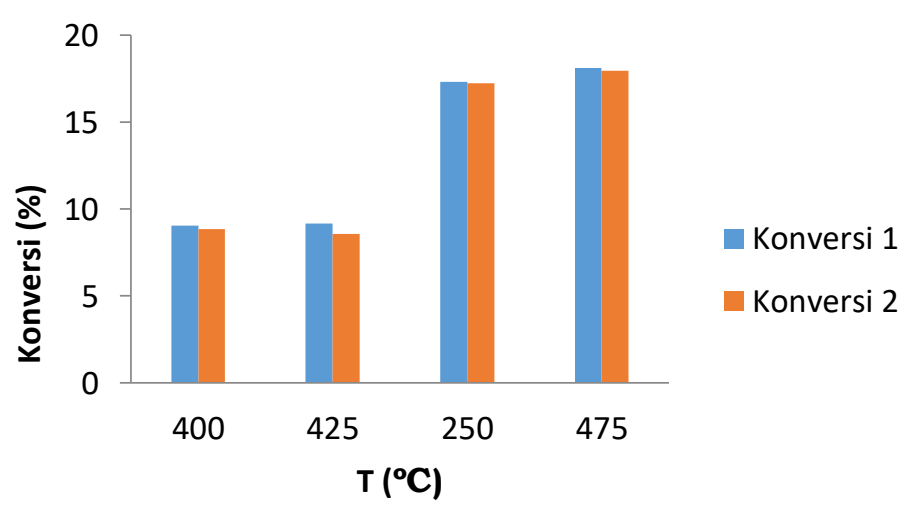

Gambar 3. Hubungan suhu terhadap hasil konversi 
Dari Gambar 3 dapat diketahui pengaruh temperatur terhadap konversi batubara menjadi produk cair didapat bahwa semakin tinggi temperatur maka semakin banyak batubara terkonversi menjadi produk cair, hal ini sama yang telah dilakukan yusnitati dan hartiniati (2017) bahwa kenaikkan temperatur secara signifikan dapat meningkatkan hasil konversi. Menurut Annisa (2016) pada penelitian konversi palatik bahwa semakin tinggi suhu dan semakin lama waktu pirolisis hasil minyak yang dihasilkan akan semakin banyak. Hal ini terjadi karena ketika laju pemanasan meningkat maka akan banyak juga gas yang terbentuk seperti $\mathrm{CO}, \mathrm{CO}_{2}, \mathrm{CH}_{4}, \mathrm{C}_{2} \mathrm{H}_{6}$ dan lainnya. Hal tersebut menunjukkan bahwa laju pemanasan yang lebih tinggi akan melepaskan gas hidrokarbon menjadi rantai-rantai pendek yang membentuk radikal.

Suhu merupakan hal penting dalam konversi. Derbyshire (1984) menjelaskan pentingnya suhu dalam pencairan batubara, karena apabila batubara diberi panas dengan tekanan yang tinggi akan terurai menjadi rantai-rantai kecil yang terdiri atas rantai aromatik, hidroaromatik maupun alifatik. Selain berpengaruh pada hasil konversi suhu juga berpengaruh pada yield yang didapatkan. Adapun yiel yang diperoleh dapat dilihat pada Gambar 4.

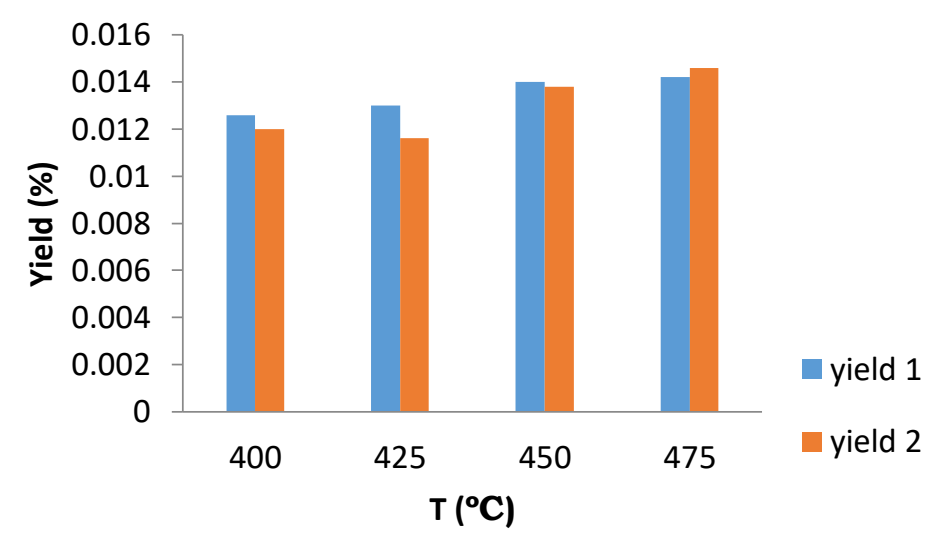

Gambar 4. Hubungan yield terhadap suhu

Hubungan yield konversi terdahap suhu dapat dilihat pada Gambar 4. Dari Gambar semakin tinggi suhu maka semakin banyak jumlah minyak yang dihasilkan. hal ini terjadi pada dua kali pengulangan. Yield menunjukan persentase tingkat kemurnian minyak yang dihasilkan. selanjutnya dari yield dapat juga menjadi suatu alat ukur untuk menilai kerja alat yang digunakan sesuai dengan yang diharapkan. Pada penelitiaan ini yiel yang tertinggi diperoleh pada saat suhu dinaikan pada 475 pada pengulangan 2 yakni sebesar $0,0146 \%$. Adapun faktor yang mempengaruh yield selain variabel yang dilakukan adalah jenis sampel batubara yang digunakan. Jenis sampel batubara yang digunakan adalah sampel batubara subbituminus. Dari hasil analisis proksimat, XRD, dan SEM-EDX. Batubara sub-bituminus termasuk batubara tingkat menengah, batubara tingkat menengah menurut harli talla amidjaya (2012). Pencairan terhadap batubara jenis lignit dan batubara jenis sub-bituminus. dari hasil didapat hasil konversi yang rendah untuk batubara jenis sub-bituminus dibanding batubara jenis lignit. Hal ini dipengaruhi oleh rasio unsur H/C. Semakin tinggi H/C maka semakin mudah batubara untuk dicairkan.

\section{Karakterisasi GC-MS (Gas Cromatografy Mass Spektroscopy)}

Merupakan secara kuantitatif yang digunakan untuk mengidentifikasi senyawa-senyawa organik yang mempunyai sifat volatil serta digunakan untuk menentukan struktur molekul senyawa analit. Adapun hasil GC-MS pada hasil konversi batubara menjadi cair ditunjukkan pada Gambar 5. 


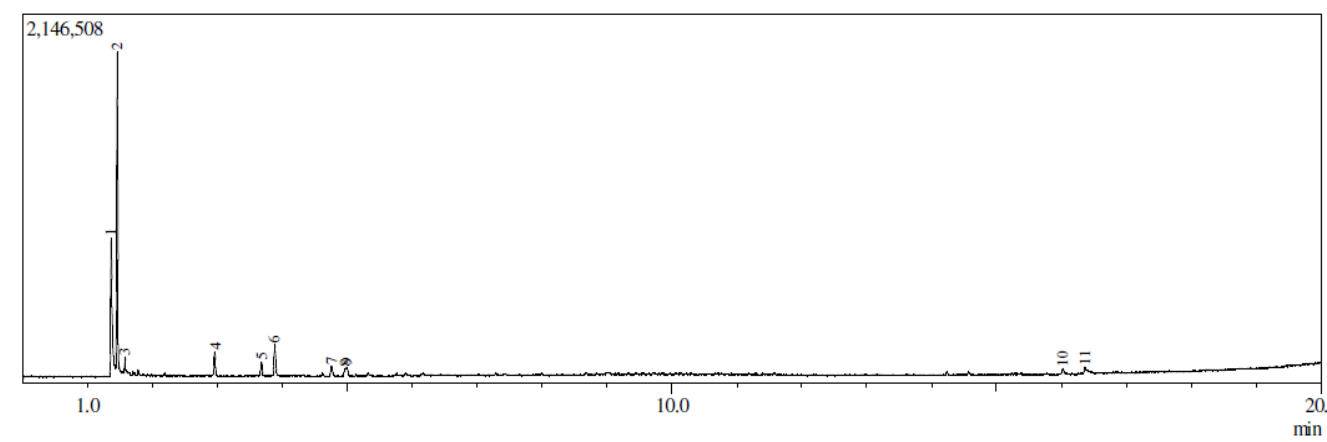

Gambar 5. Spectra GC-MS Konversi Batubara Menjadi Produk Cair

Dari Gambar 5 terdapat 11 puncak yang muncul pada hasil konversi batubara. Untuk mengetahui senyawa struktur molekul yang muncul dapat dilihat dari hasil spektrometri massanya.Ssenyawa-senyawa yang teridentifikasi pada analisis GC-MS dengan waktu retensinyadisajikandalamTabel 5.

Tabel 5.Senyawa-senyawa yang terbentuk pada konversi batubara menjadi produk cair

\begin{tabular}{ccccllc}
\hline Peak & R.Time (min) & \% Area & $\mathbf{m} / \mathbf{z}$ & Rumusmolekul & Senyawa & $\mathbf{m} / \mathbf{z}$ \\
\hline $\mathbf{1}$ & 1.367 & 28.52 & 392 & $\mathrm{C}_{2} \mathrm{H}_{5} \mathrm{ClO}_{2} \mathrm{~S}$ & EthanesulfonylClorida & 93 \\
$\mathbf{2}$ & 1.461 & 45.03 & 294 & $\mathrm{C}_{2} \mathrm{H}_{4} \mathrm{O}_{2}$ & Acetid Acid & 60 \\
$\mathbf{3}$ & 1.581 & 4.29 & 275 & $\mathrm{C}_{3} \mathrm{H}_{6} \mathrm{O}_{2}$ & Propanoic Acid & 74 \\
$\mathbf{4}$ & 2.962 & 4.31 & 264 & $\mathrm{C}_{6} \mathrm{H}_{6} \mathrm{O}_{4} \mathrm{~S}$ & 4-hydroxy benzenesulfonic acid & 94 \\
$\mathbf{6}$ & 3.886 & 6.44 & 258 & $\mathrm{C}_{7} \mathrm{H}_{8} \mathrm{O}$ & Phenol, 3- methyl & 108 \\
\hline
\end{tabular}

Dari Tabel5 diketahui bahwa metode yang digunakan telah bekerja sesuai dengan yang diharapkan. Hal ini ditandai dengan adanya senyawa hidrokarbon rantai pendek yaitu $\mathrm{C}_{2}$ sampai $\mathrm{C}_{7}$. Adanya hidrokarbon rantai pendek ini menunjukkan bahwa batubara berpotensi sebagai bahan dalam pembuatan bensin. Mulyono (2005) bensin adalah campuran senyawa alkana cair dengan rantai $\mathrm{C}_{6}-\mathrm{C}_{8}, \mathrm{C}_{6}-\mathrm{C}_{14}, \mathrm{C}_{7}-\mathrm{H}_{16}, \mathrm{C}_{8}-\mathrm{H}_{18}$ dapat lurut atau bercabang. Pada penelitian ini, berdasarkan GC-MS produk yang dihasilkan masih belum murni yaitu adanya unsur O (Oksigen) yang berikatan dengan hidrokarbon. Dari hasil GC-MS selain unsur O. Peak 1 dan 4 diketahui adanya unsur S (sulfur). Hal ini membuktikan bahwa konversi menggunakan teknik pirolisis mempunyai kelemahan yaitu perlunya dilakukan pemurnian terhadap hasil konversi. Adanya unsur $\mathrm{O}$ dikarenakan pada sampel batubara yang digunakan terdapat air. Adapun kandungan air pada analisis proksimat pada sampel batubara sebesar 11,9\%. Dari hasil juga menunjukkan adanya hidrokarbon yang berikatan dengan $\mathrm{S}$. Adanya unsur $\mathrm{S}$ dikarenakan pada batubara yang digunakan juga terdapat $\mathrm{S}$, selain itu juga terdapat pada pelarut yang digunakan.

\section{SIMPULAN}

Dari hasil karakterisasi batubara, Batubara PT. Daya bambu merupakan batubara sub-bituminus yang termasuk kedalam batubara peringkat menengah. semakin tinggi peringkat batubara maka semakin baik kualitasnya. Dan semakin baik kualitas batubara maka semakin susah batubara tersebut untuk dikonversikan menjadi produk cair. Pada penelitian dilakukan konversi batubara dengan melihat pengaruh suhu terhadap hasil konversi. Dari hasil konversi peningkatan suhu dapat juga meningkatkan hasil konversi dan yield yang diperoleh. Dari hasil konversi batubara pada analisis GC-MS menunjukan batubara dapat menjadi alternatif sebagai pengganti bahan baku bensin yaitu terbentuknya senyawa hidrokarbon rantai $C_{7}-C_{n}$.

\section{DAFTAR PUSTAKA}

American Society for Testing and Material,.2015. Proximate Analysis of Coal and Coke Volume 5. American Society of Testing and Material.

American Society for Testing and Material,.2015. Moisture in the Analysis of Coal and Coke. Volume 5. American Society of Testing and Material.

American Society for Testing and Material,.2015. Ash in the Analysis Sample of Coal and Coke. Volume 5. American Society of Testing and Material. 
American Society for Testing and Material ,.2015. Proximate Analysis of Coal and Coke Volatile Matter in the Analysis of Coal and Coke Volatile. Volume 5. American Society of Testing and Material.

American Society for Testing and Material,.2015. Total Moisture in Coal. Volume 5. American Society of Testing and Material.

American Society for Testing and Materials,.1982. Petroleum Product and Lubricants. Part 23. Philadelphia: Copyright Annual Book of ASTM standard.

ASTM Standar D 3176-89, 2009, Standard Practice for Ultimate Analysis of Coal and Coke, Volume 05.06, Gaseous Fuels, Coal and Coke, $6 \mathrm{p}$

ASTM Standar D 5373 -08, 2009, Standard Test Methods for Instrumental Determination of Carbon, Hydrogen, and Nitrogen in Laboratory Samples of Coal, Volume 05.06, Gaseous Fuel, Coal and Coke, $22 \mathrm{p}$.

Huda,M., Hermanu, A., Talla, H., dan Indra,I., 2009. Pencairan BatubaraPeringkat Rendah (Batubara Pendopo) Sumatra Selatan. Inhouse Research tekMIRA. Bandung, pp.52

Kleinpeter, J.A., 2008. Coal Liquefaction Products, John Wiley \& Sons inc., $\quad$ New York, pp. 1-413.

Nukman.,2007. Pengaruh Pencampuran Batubara Muda Dari Sumatera Selatan Dan Kalimantan Selatan Terhadap Suhu Pembakarannya Dengan Menggunakan Fixed Bed Combustor. Jurnal Sains Materi Indonesia Indonesian Journal of Materials Science: Vol. 10, No. 3, Juni 2009, hal : $284-287$

Speight J.G., 2005, Handbook of Coal Analysis, John Wiley \& Sons, Inc., Publication, 222 p.

Talla,H., 2012, Karakteristik Batubara dan Pengaruhnya Terhadap Proses Konversi Dengan Menggunakan Metode Hidrogenasi Katalitik,Tesis, Universitas Gadjah Mada, 98 hal.

Yusnitati, 2017. Efektivitas Penambahan Nikel Pada Pencairan Batubara Peringkat Rendah Menggunakan Katalis Alami Limonit. Pusat teknologikonversi dan konservasi energy badan pengkajian dan penerapan teknologi

Shi, S., Li, W., Wang, Y., Guo, Z. and Li, K. (2010). "Study On Mechanism Of Coal

Liquefaction Reaction And A New Process Concept".Journal of Coal Science \& Engineering (China), 14(1), 119-124.

Badan Pusat Statistik. 2014. Jumlah Kendaraan Bermotor Provinsi DIY tahun 2013. Yogyakarta: Badan Pusat Statistik

Derbyshire, F.J., Odoerfer G.A., dan Whitehurst, D.D., 1984. Coal dissolution in nitrogen compounds, Fuel, 63 , h. 56-60

Wang,Z., Bai,Z., Li,W., Chen,H., and Li,B. 2010. Quantitative Study on Cross-Linking Reaction of Oxygen Groups During Liquefaction of Ligniteby a New Model System, Fuel Processing Technology, Vol.91, pp. 410-413. 